\title{
Opportunities for Sustainable Low Carbon Energy Research Development and Applications
}

\begin{abstract}
Abdeen Mustafa Omer
Energy Research Institute (ERI), Nottingham, United Kingdom.

Email: abdeenomer2@yahoo.co.uk

Received March 1 ${ }^{\text {st }}, 2011$; revised March 28 ${ }^{\text {th }}, 2011$; accepted April $3^{\text {rd }}, 2011$.

ABSTRACT

People to rely upon oil for primary energy and this for a few more decades. Other conventional sources may be more enduring, but are not without serious disadvantages. The renewable energy resources are particularly suited for the provision of rural power supplies and a major advantage is that equipment such as flat plate solar driers, wind machines, etc., can be constructed using local resources and without the advantage results from the feasibility of local maintenance and the general encouragement such local manufacture gives to the build up of small-scale rural based industry. This article comprises a comprehensive review of energy sources, the environment and sustainable development. It includes the renewable energy technologies, energy efficiency systems, energy conservation scenarios, energy savings in greenhouses environment and other mitigation measures necessary to reduce climate change. This article gives some examples of small-scale energy converters, nevertheless it should be noted that small conventional, i.e, engines are currently the major source of power in rural areas and will continue to be so for a long time to come. There is a need for some further development to suit local conditions, to minimise spares holdings, to maximise interchangeability both of engine parts and of the engine application. Emphasis should be placed on full local manufacture. It is concluded that renewable environmentally friendly energy must be encouraged, promoted, implemented and demonstrated by full-scale plant especially for use in remote rural areas.
\end{abstract}

Keywords: Renewable Energy Technologies, Energy Efficiency, Sustainable Development, Emissions, Environment

\section{Introduction}

Power from natural resources has always had great appeal. Coal is plentiful, though there is concern about despoliation in winning it and pollution in burning it. Nuclear power has been developed with remarkable timeliness, but is not universally welcomed, construction of the plant is energy-intensive and there is concern about the disposal of its long-lived active wastes. Barrels of oil, lumps of coal, even uranium come from nature but the possibilities of almost limitless power from the atmosphere and the oceans seem to have special attraction. The wind machine provided an early way of developing motive power. The massive increases in fuel prices over the last years have however, made any scheme not requiring fuel appear to be more attractive and to be worth reinvestigation. In considering the atmosphere and the oceans as energy sources the four main contenders are wind power, wave power, tidal and power from ocean thermal gradients. The sources to alleviate the energy situation in the world are sufficient to supply all foresee able needs.
Conservation of energy and rationing in some form will however have to be practised by most countries, to reduce oil imports and redress balance of payments positions. Meanwhile development and application of nuclear power and some of the traditional solar, wind and water energy alternatives must be set in hand to supple- ment what remains of the fossil fuels.

The encouragement of greater energy use is an essential component of development. In the short term, it requires mechanisms to enable the rapid increase in energy/capita, while in the long term it may require the use of energy efficiency without environmental and safety concerns. Such programmes should as far as possible be based on renewable energy resources. Large-scale, conventional, power plant such as hydropower has an important part to play in development although it does not provide a complete solution. There is however an important complementary role for the greater use of small scale, rural based, power plants. Such plants can be employed to assist development since they can be made locally. Renewable resources are particularly suitable for provid- 
ing the energy for such equipment and its use is also compatible with the long-term aims.

In compiling energy consumption data one can categorise usage according to a number of different schemes:

- Traditional sector-industrial, transportation, etc.

- $\quad$ End-use - space heating, process steam, etc.

- Final demand - total energy consumption related to automobiles, to food, etc.

- Energy source-oil, coal, etc.

- Energy form at point of use-electric drive, low temperature heat, etc.

\section{Renewable Energy Potential}

The increased availability of reliable and efficient energy services stimulates new development alternatives [1]. This article discusses the potential for such integrated systems in the stationary and portable power market in response to the critical need for a cleaner energy technology. Anticipated patterns of future energy use and consequent environmental impacts (acid precipitation, ozone depletion and the greenhouse effect or global warming) are comprehensively discussed in this paper. Throughout the theme several issues relating to renewable energies, environment and sustainable development are examined from both current and future perspectives. It is concluded that renewable environmentally friendly energy must be encouraged, promoted, implemented and demonstrated by full-scale plant especially for use in remote rural areas. Globally, buildings are responsible for approximately $40 \%$ of the total world annual energy consumption. Most of this energy is for the provision of lighting, heating, cooling, and air conditioning. Increasing awareness of the environmental impact of $\mathrm{CO}_{2}$ and $\mathrm{NO}_{\mathrm{x}}$ and CFCs emissions triggered a renewed interest in environmentally friendly cooling, and heating technologies. Under the 1997 Montreal Protocol, governments agreed to phase out chemicals used as refrigerants that have the potential to destroy stratospheric ozone. It was therefore considered desirable to reduce energy consumption and decrease the rate of depletion of world energy reserves and pollution of the environment. One way of reducing building energy consumption is to design buildings, which are more economical in their use of energy for heating, lighting, cooling, ventilation and hot water supply. Passive measures, particularly natural or hybrid ventilation rather than air-conditioning, can dramatically reduce primary energy consumption. However, exploitation of renewable energy in buildings and agricultural greenhouses can, also, significantly contribute towards reducing dependency on fossil fuels. Therefore, promoting innovative renewable applications and reinforcing the renewable energy market will contribute to preservation of the ecosystem by reducing emissions at local and global levels. This will also contribute to the amelioration of environmental conditions by replacing conventional fuels with renewable energies that produce no air pollution or greenhouse gases.

There is strong scientific evidence that the average temperature of the earth's surface is rising. This is a result of the increased concentration of carbon dioxide and other GHGs in the atmosphere as released by burning fossil fuels. This global warming will eventually lead to substantial changes in the world's climate, which will, in turn, have a major impact on human life and the built environment. Therefore, effort has to be made to reduce fossil energy use and to promote green energies, particularly in the building sector. Energy use reductions can be achieved by minimising the energy demand, by rational energy use, by recovering heat and the use of more green energies. This study was a step towards achieving that goal. The adoption of green or sustainable approaches to the way in which society is run is seen as an important strategy in finding a solution to the energy problem. The key factors to reducing and controlling $\mathrm{CO}_{2}$, which is the major contributor to global warming, are the use of alternative approaches to energy generation and the exploration of how these alternatives are used today and may be used in the future as green energy sources [2]. Even with modest assumptions about the availability of land, comprehensive fuel-wood farming programmes offer significant energy, economic and environmental benefits. These benefits would be dispersed in rural areas where they are greatly needed and can serve as linkages for further rural economic development. The nations as a whole would benefit from savings in foreign exchange, improved energy security, and socio-economic improvements. With a nine-fold increase in forest - plantation cover, a nation's resource base would be greatly improved. The international community would benefit from pollution reduction, climate mitigation, and the increased trading opportunities that arise from new income sources. The non-technical issues, which have recently gained attention, include: 1) Environmental and ecological factors, e.g., carbon sequestration, reforestation and revegetation; 2) Renewables as a $\mathrm{CO}_{2}$ neutral replacement for fossil fuels; 3) Greater recognition of the importance of renewable energy, particularly modern biomass energy carriers, at the policy and planning levels; 4) Greater recognition of the difficulties of gathering good and reliable renewable energy data, and efforts to improve it; 5) Studies on the detrimental health efforts of biomass energy particularly from traditional energy users. The renewable energy resources are particularly suited for the provision of rural power supplies and a major advantage is that equipment such as flat plate solar driers, wind machines, etc., can be constructed using local re- 
sources and without the advantage results from the feasibility of local maintenance and the general encouragement such local manufacture gives to the build up of small scale rural based industry. This article gives some examples of small-scale energy converters, nevertheless it should be noted that small conventional, i.e, engines are currently the major source of power in rural areas and will continue to be so for a long time to come. There is a need for some further development to suit local conditions, to minimise spares holdings, to maximise interchangeability both of engine parts and of the engine application. Emphasis should be placed on full local manufacture.

The renewable energy resources are particularly suited for the provision of rural power supplies and a major advantage is that equipment such as flat plate solar driers, wind machines, etc., can be constructed using local resources and without the high capital cost of more conventional equipment. Further advantage results from the feasibility of local maintenance and the general encouragement such local manufacture gives to the build up of small scale rural based industry. Table 1 lists the energy sources available.

Currently the 'non-commercial' fuels wood, crop residues and animal dung are used in large amounts in the rural areas of developing countries, principally for heating and cooking; the method of use is highly inefficient. Table 2 presented some renewable applications.

Table 3 lists the most important of energy needs.

Considerations when selecting power plant include the following:

- Power level-whether continuous or discontinuous.

- Cost - initial cost, total running cost including fuel, maintenance and capital amortised over life.

- Complexity of operation.

- Maintenance and availability of spares.

Table 1. Sources of energy [3].

\begin{tabular}{ccc}
\hline Energy source & Energy carrier & Energy end-use \\
\hline Vegetation & Fuel-wood & $\begin{array}{c}\text { Cooking } \\
\text { Water heating } \\
\text { Building materials } \\
\text { Animal fodder preparation }\end{array}$ \\
Oil & Kerosene & $\begin{array}{c}\text { Lighting } \\
\text { Ignition fires }\end{array}$ \\
Dry cells & Dry cell batteries & $\begin{array}{c}\text { Lighting } \\
\text { Small appliances }\end{array}$ \\
& & Transport \\
Muscle power & Animal power & $\begin{array}{c}\text { Land preparation for farming } \\
\text { Food preparation (threshing) }\end{array}$ \\
& & Transport \\
Muscle power & Human power & $\begin{array}{c}\text { Land preparation for farming } \\
\text { Food preparation (threshing) }\end{array}$ \\
\hline
\end{tabular}

Table 2. Renewable applications [4].

\begin{tabular}{cl}
\hline Systems & \multicolumn{1}{c}{ Applications } \\
\hline Water supply & $\begin{array}{l}\text { Rain collection, purification, storage and } \\
\text { recycling } \\
\text { Anaerobic digestion }\left(\mathrm{CH}_{4}\right)\end{array}$ \\
Wastes disposal & Methane \\
Cooking & Cultivate the 1 hectare plot and greenhouse \\
Food & for four people \\
& Wind generator \\
Electrical demands & Solar collectors \\
Space heating & Solar collectors and excess wind energy \\
Water heating & Ultimately hardware \\
Control system & Integration of subsystems to cut costs \\
Building fabric &
\end{tabular}

Table 3. Energy needs in rural areas [6].

\begin{tabular}{cc} 
Muscle power & Man, animals \\
Internal combustion engines & \\
Reciprocating & Petrol-spark ignition \\
Rotating & $\begin{array}{c}\text { Diesel-compression ignition } \\
\text { Humphrey water piston }\end{array}$ \\
Heat engines & Gas turbines \\
Vapour (Rankine) & \\
Reciprocating & \\
Rotating & Steam engine \\
Gas Stirling (Reciprocating) & Steam turbine \\
Gas Brayton (Rotating) & Steam engine \\
Electron gas & Steam turbine \\
Electromagnetic radiation & Thermionic, thermoelectric \\
Hydraulic engines & Photo devices \\
Wind engines (wind machines) & Wheels, screws, buckets, turbines \\
Electrical/mechanical & Dynamo/alternator, motor \\
\hline
\end{tabular}

- Life.

- $\quad$ Suitability for local manufacture.

Table 4 listed methods of energy conversion.

There is a need for greater attention to be devoted to this field in the development of new designs, the dissemination of information and the encouragement of its use. International and government bodies and independent organisations all have a role to play in renewable energy technologies.

Table 4. Methods of energy conversion [7].

Transport, e.g., small vehicles and boats

Agricultural machinery, e.g., two-wheeled tractors

Crop processing, e.g., milling

Water pumping

Small industries, e.g., workshop equipment

Electricity generation, e.g., hospitals and schools

Domestic, e.g., cooking, heating, and lighting

Water supply, e.g., rain collection, purification, storage and reccling

Building fabric, e.g., integration of subsystems to cut costs

Wastes disposal, e.g., anaerobic digestion $\left(\mathrm{CH}_{4}\right)$ 
The household wastes, i.e., for family of four persons, could provide $280 \mathrm{kWh} / \mathrm{yr}$ of methane, but with the addition of vegetable wastes from 0.2 ha or wastes from 1 ha growing a complete diet, about $1500 \mathrm{kWh} / \mathrm{yr}$ may be obtained by anaerobic digestion [5]. The sludge from the digester may be returned to the land. In hotter climates, this could be used to set up a more productive cycle (Figure 1).

Society and industry in Europe and elsewhere are increasingly dependent on the availability of electricity supply and on the efficient operation of electricity systems. In the European Union (EU), the average rate of growth of electricity demand has been about $1.8 \%$ per year since 1990 and is projected to be at least $1.5 \%$ yearly up to 2030 [8]. Currently, distribution networks generally differ greatly from transmission networks, mainly in terms of role, structure (radial against meshed) and consequent planning and operation philosophies.

\subsection{Energy Consumption}

Over the last decades, natural energy resources such as petroleum and coal have been consumed at high rates. The heavy reliance of the modern economy on these fuels are bound to end, due to their environmental impact, and the fact that conventional sources might eventually run out. The increasing price of oil and instabilities in the oil market led to search for energy substitutes.

In addition to the drain on resources, such an increase in consumption consequences, together with the increased hazards of pollution and the safety problems associated with a large nuclear fission programmes. This is a disturbing prospect. It would be equally unacceptable to suggest that the difference in energy between the developed and developing countries and prudent for the developed countries to move towards a way of life which, whilst maintaining or even increasing quality of life, reduce significantly the energy consumption per capita.

Such savings can be achieved in a number of ways:

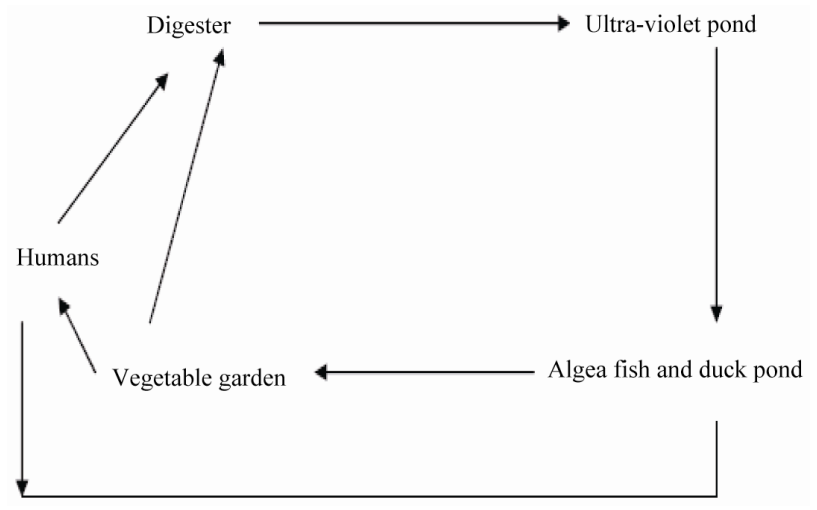

Figure 1. Biomass energy utilisation cycle [9].
- Improved efficiency of energy use, for example better thermal insulation, energy recovery, and total energy.

- Conservation of energy resources by design for long life and recycling rather than the short life throwaway product.

- Systematic replanning of our way of life, for example in the field of transport.

Energy ratio is defined as the ratio of:

Energy content of the food product/Energy input to produce the food

A review of the potential range of recyclables is presented in Table 5.

Currently the non-commercial fuelwood, crop residues and animal dung are used in large amounts in the rural areas of developing countries, principally for heating and cooking, the method of use is highly inefficient. As in the developed countries, the fossil fuels are currently of great importance in the developing countries. Geothermal and tidal energy are less important though, of course, will have local significance where conditions are suitable. Nuclear energy sources are included for completeness, but are not likely to make any effective contribution in the rural areas.

\subsection{Biogas Production}

Biogas is a generic term for gases generated from the decomposition of organic material. As the material breaks down, methane $\left(\mathrm{CH}_{4}\right)$ is produced as shown in Figure 2. Sources that generate biogas are numerous and varied. These include landfill sites, wastewater treatment plants and anaerobic digesters [11]. Landfills and wastewater treatment plants emit biogas from decaying waste. To date, the waste industry has focused on controlling these emissions to our environment and in some cases, tapping this potential source of fuel to power gas turbines, thus generating electricity [12]. The primary components of landfill gas are methane $\left(\mathrm{CH}_{4}\right)$, carbon dioxide $\left(\mathrm{CO}_{2}\right)$, and nitrogen $\left(\mathrm{N}_{2}\right)$. The average concentration of methane is $\sim 45 \%, \mathrm{CO}_{2}$ is $\sim 36 \%$ and nitrogen is $\sim 18 \%$ [13]. Other components in the gas are oxygen $\left(\mathrm{O}_{2}\right)$, water vapour and trace amounts of a wide range of non-methane organic compounds (NMOCs). Landfill gas-to-cogeneration projects present a win-win-win situation. Emissions of particularly damaging pollutant are avoided, electricity is generated from a free fuel and heat is available for use locally.

\subsection{Wave Power Conversion Devices}

The patent literature is full of devices for extracting energy from waves, i.e, floats, ramps, and flaps, covering channels [14]. Small generators driven from air trapped 
Table 5. Summary of material recycling practices in the construction sector [10].

\begin{tabular}{|c|c|c|}
\hline $\begin{array}{l}\text { Construction and } \\
\text { demolition material }\end{array}$ & $\begin{array}{l}\text { Recycling technology } \\
\text { options }\end{array}$ & Recycling product \\
\hline Asphalt & $\begin{array}{l}\text { Cold recycling: heat } \\
\text { generation; Minnesota } \\
\text { process; parallel drum } \\
\text { process; elongated } \\
\text { drum; microwave as- } \\
\text { phalt recycling sys- } \\
\text { tem; finfalt; surface } \\
\text { regeneration }\end{array}$ & $\begin{array}{l}\text { Recycling asphalt; } \\
\text { asphalt aggregate }\end{array}$ \\
\hline Brick & $\begin{array}{l}\text { Burn to ash, crush } \\
\text { into aggregate }\end{array}$ & $\begin{array}{l}\text { Slime burn ash; filling } \\
\text { material; hardcore }\end{array}$ \\
\hline Concrete & Crush into aggregate & $\begin{array}{l}\text { Recycling aggregate; } \\
\text { cement replacement; } \\
\text { protection of levee; } \\
\text { backfilling; filter }\end{array}$ \\
\hline Ferrous metal & Melt; reuse directly & Recycled steel scrap \\
\hline Glass & $\begin{array}{l}\text { Reuse directly; grind } \\
\text { to powder; polishing; } \\
\text { crush into aggregate; } \\
\text { burn to ash }\end{array}$ & $\begin{array}{l}\text { Recycled window } \\
\text { unit; glass fibre; fill- } \\
\text { ing material; tile; } \\
\text { paving block; asphalt; } \\
\text { recycled aggregate; } \\
\text { cement replacement; } \\
\text { manmade soil }\end{array}$ \\
\hline Masonry & $\begin{array}{l}\text { Crush into aggregate; } \\
\text { heat to } 900^{\circ} \mathrm{C} \text { to ash }\end{array}$ & $\begin{array}{l}\text { Thermal insulating } \\
\text { concrete; traditional } \\
\text { clay }\end{array}$ \\
\hline Non-ferrous metal & Melt & Recycled metal \\
\hline Paper and cardboard & Purification & Recycled paper \\
\hline Plastic & $\begin{array}{l}\text { Convert to powder by } \\
\text { cryogenic milling; } \\
\text { clopping; crush into } \\
\text { aggregate; burn to ash }\end{array}$ & $\begin{array}{l}\text { Panel; recycled plas- } \\
\text { tic; plastic lumber; } \\
\text { recycled aggregate; } \\
\text { landfill drainage; as- } \\
\text { phalt; manmade soil }\end{array}$ \\
\hline Timber & $\begin{array}{l}\text { Reuse directly; cut } \\
\text { into aggregate; blast } \\
\text { furnace deoxidisation; } \\
\text { gasification or pyro- } \\
\text { lysis; chipping; } \\
\text { moulding by pressur- } \\
\text { ising timber chip un- } \\
\text { der steam and water }\end{array}$ & $\begin{array}{l}\text { Whole timber; furni- } \\
\text { ture and kitchen uten- } \\
\text { sils; lightweight recy- } \\
\text { cled aggregate; source } \\
\text { of energy; chemical } \\
\text { production; } \\
\text { wood-based panel; } \\
\text { plastic lumber; geofi- } \\
\text { bre; insulation board }\end{array}$ \\
\hline
\end{tabular}

by the rising and falling water in the chamber of a buoy are in use around the world [15]. Wave power is one possibility that has been selected Figure 3 shows the many other aspects that will need to be covered. A wave power programme would make a significant contribution to energy resources within a relatively short time and with existing technology.

Wave energy has also been in the news recently. There is about 140 megawatts per mile available round British coasts. It could make a useful contribution people needs in the UK. Although very large amounts of power are

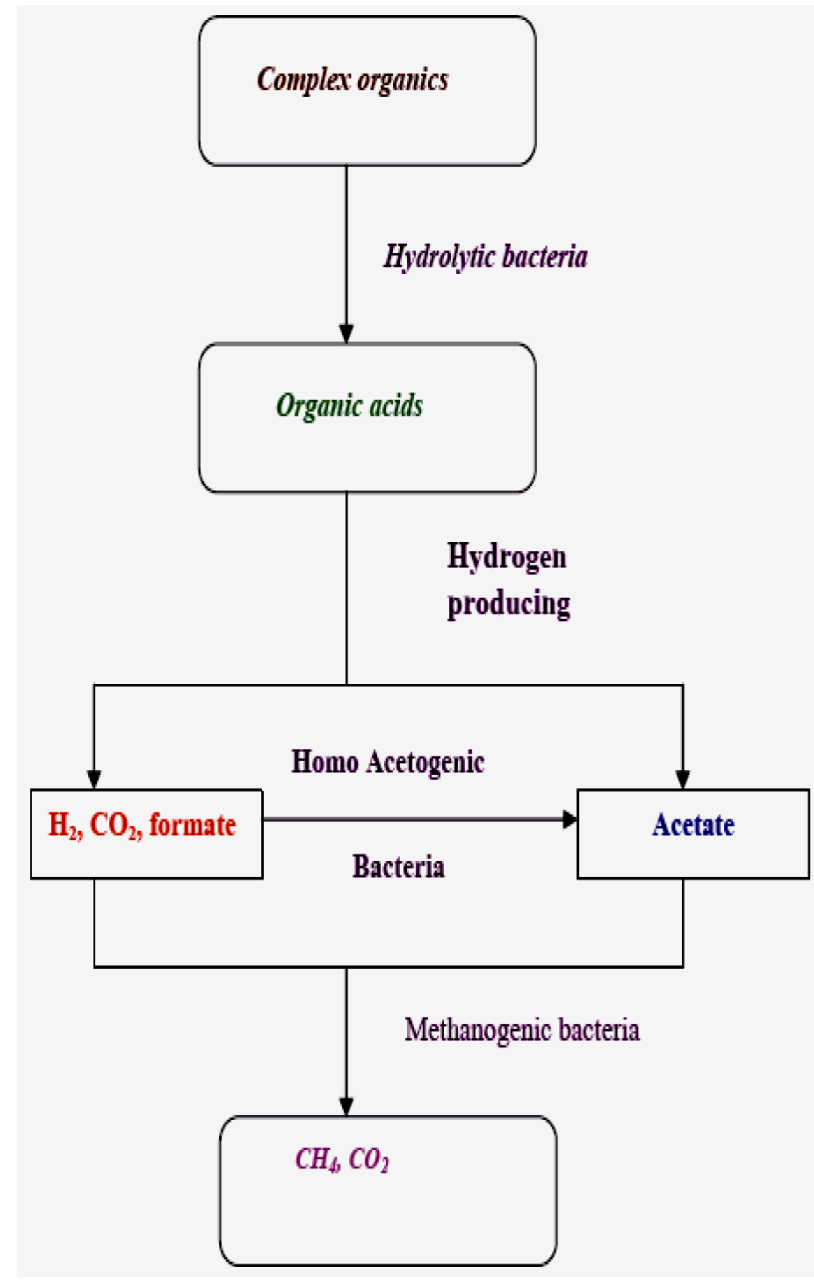

Figure 2. Biogas production process [14].

available in the waves, it is important to consider how much power can be extracted. A few years ago only a few percent efficiency had been achieved. Recently, however, several devices have been studied which have very high efficiencies. Some form of storage will be essential on a second-to-second and minute-to-minute basis to smooth the fluctuations of individual waves and wave's packets but storage from one day to the next will certainly not be economical. This is why provision must be made for adequate standby capacity.

The increased availability of reliable and efficient energy services stimulates new development alternatives. This article discusses the potential for such integrated systems in the stationary and portable power market in response to the critical need for a cleaner energy technology. Anticipated patterns of future energy use and consequent environmental impacts (acid precipitation, ozone depletion and the greenhouse effect or global warming) are comprehensively discussed in this paper. Throughout the theme several issues relating to renew- 


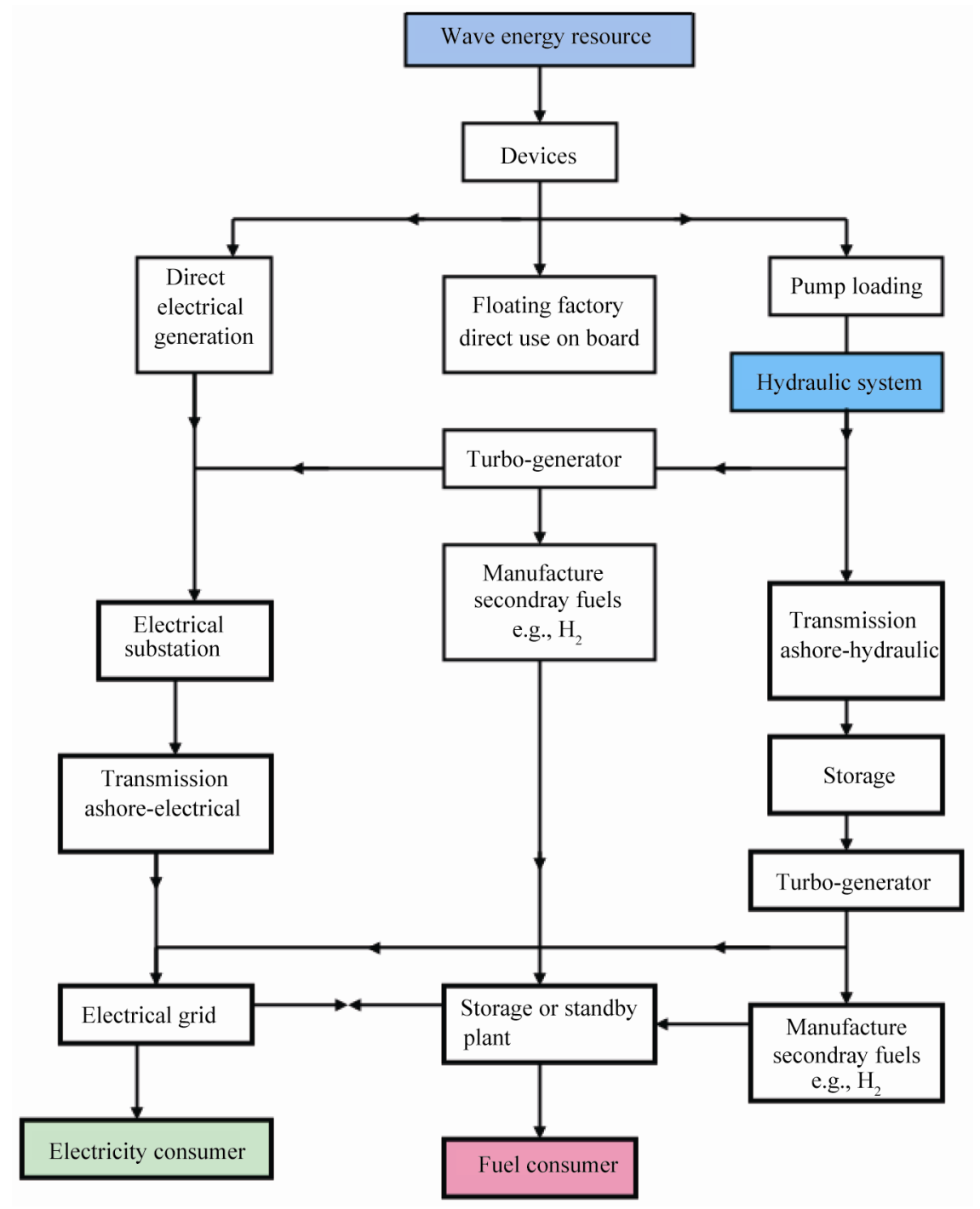

Figure 3. Possible systems for exploiting wave power, each element represents an essential link in the chain from sea waves to consumer [15].

able energies, environment and sustainable development are examined from both current and future perspectives. It is concluded that renewable environmentally friendly energy must be encouraged, promoted, implemented and demonstrated by full-scale plant especially for use in remote rural areas. Globally, buildings are responsible for approximately $40 \%$ of the total world annual energy consumption. Most of this energy is for the provision of lighting, heating, cooling, and air conditioning. Increasing awareness of the environmental impact of $\mathrm{CO}_{2}$ and $\mathrm{NO}_{\mathrm{x}}$ emissions and CFCs triggered a renewed interest in environmentally friendly cooling, and heating technologies. Under the 1997 Montreal Protocol, governments agreed to phase out chemicals used as refrigerants that have the potential to destroy stratospheric ozone. It was therefore considered desirable to reduce energy con- sumption and decrease the rate of depletion of world energy reserves and pollution of the environment. One way of reducing building energy consumption is to design buildings, which are more economical in their use of energy for heating, lighting, cooling, ventilation and hot water supply. Passive measures, particularly natural or hybrid ventilation rather than air-conditioning, can dramatically reduce primary energy consumption. However, exploitation of renewable energy in buildings and agricultural greenhouses can, also, significantly contribute towards reducing dependency on fossil fuels. Therefore, promoting innovative renewable applications and reinforcing the renewable energy market will contribute to preservation of the ecosystem by reducing emissions at local and global levels. This will also contribute to the amelioration of environmental conditions by replacing 
conventional fuels with renewable energies that produce no air pollution or greenhouse gases. The provision of good indoor environmental quality while achieving energy and cost efficient operation of the heating, ventilating and air-conditioning (HVAC) plants in buildings represents a multi variant problem. The comfort of building occupants is dependent on many environmental parameters including air speed, temperature, relative humidity and quality in addition to lighting and noise. The overall objective is to provide a high level of building performance (BP), which can be defined as indoor environmental quality (IEQ), energy efficiency (EE) and cost efficiency (CE).

\subsection{Ethanol Production}

Alternative fuels were defined as methanol, ethanol, natural gas, propane, hydrogen, coal-derived liquids, biological material and electricity production [8]. The fuel pathways currently under development for alcohol fuels are shown in Figure 4. The production of agricultural biomass and its exploitation for energy purposes can contribute to alleviate several problems, such as the dependence on import of energy products, the production of food surpluses, the pollution provoked by the use of fossil fuels, the abandonment of land by farmers and the connected urbanisation. Biomass is not at the moment competitive with mineral oil, but, taking into account also indirect costs and giving a value to the aforementioned advantages, public authorities at national and international level can spur its production and use by incentives of different nature. In order to address the problem of inefficiency, research centres around the world have investigated the viability of converting the resource to a more useful form, namely solid briquettes and fuel gas [1] (Figure 5).
The main advantages are related to energy, agriculture and environment problems, are foreseeable both at regional level and at worldwide level and can be summarised as follows:

- Reduction of dependence on import of energy and related products.

- Reduction of environmental impact of energy production (greenhouse effect, air pollution, and waste degradation).

- Substitution of food crops and reduction of food surpluses and of related economic burdens, utilisation of marginal lands and of set aside lands.

- Reduction of related socio-economic and environmental problems (soil erosion, urbanisation, landscape deterioration, etc.).

- Development of new know-how and production of technological innovation.

Biomass resources play a significant role in energy supply in all developing countries. Biomass resources should be divided into residues or dedicated resources, the latter including firewood and charcoal can also be produced from forest residues. Ozone $\left(\mathrm{O}_{3}\right)$ is a naturally occurring molecule that consists of three oxygen atoms held together by the bonding of the oxygen atoms to each other. The effects of the chlorofluorocarbons (CFCs) molecule can last for over a century. This reaction is shown in Figure 6.

It is a common misconception that the reason for recycling old fridge is to recover the liquid from the cooling circuit at the back of the unit. The insulating foams used inside some fridges act as sinks of CFCs- the gases having been used as blowing agents to expand the foam during fridge manufacture. Although the use of ozone depleting chemicals in the foam in fridges has declined in the West, recyclers must consider which strategy to adopt

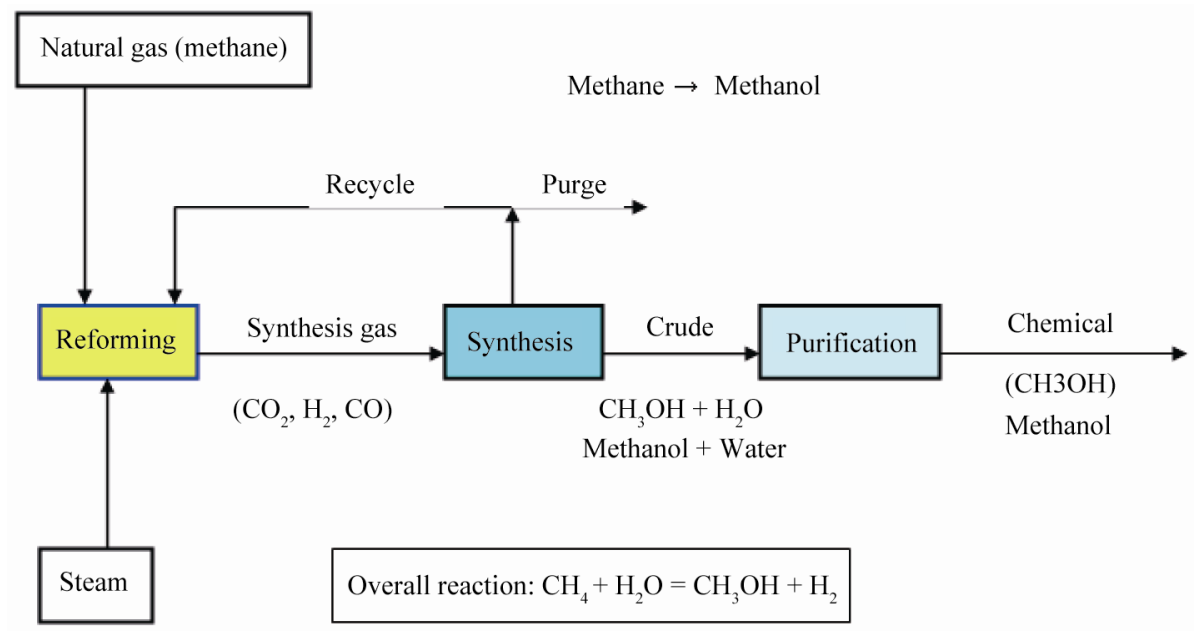

Figure 4. Schematic process flowsheet [4]. 


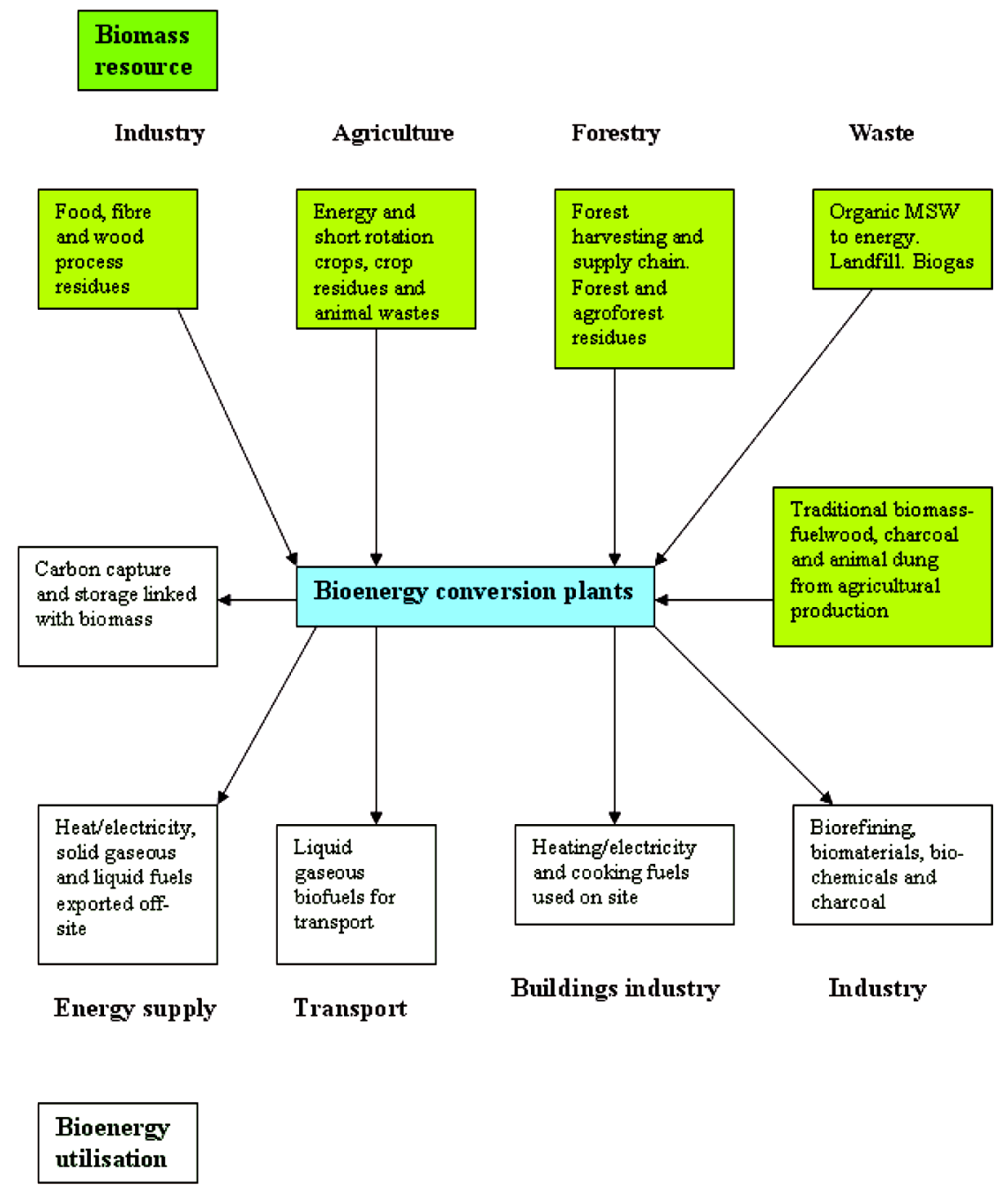

Figure 5. Biomass resources from several sources are converted into a range of products for use by transport, industry and building sectors [3].

to deal with the disposal problem they still present each year. It is common practice to dispose of this waste wood in landfill where it slowly degraded and takes up valuable void space. This wood is a good source of energy and is an alternative to energy crops. Agricultural wastes are abundantly available globally and can be converted to energy and useful chemicals by a number of microorganisms. The success of promoting any technology depends on careful planning, management, implementation, training and monitoring. Main features of gasification project are:

- Networking and institutional development/strengthening.

- Promotion and extension.

- Construction of demonstration projects.

- Research and development, and training and monitoring.

\subsection{Biomass CHP}

Combined heat and power (CHP) installations are quite common in greenhouses, which grow high-energy, input crops (e.g., salad vegetables, pot plants, etc.). Scientific assumptions for a short-term energy strategy suggest that the most economically efficient way to replace the thermal plants is to modernise existing power plants to increase their energy efficiency and to improve their environmental performance. However, utilisation of wind power and the conversion of gas-fired CHP plants to biomass would significantly reduce the dependence on imported fossil fuels. Although a lack of generating capacity is forecast in the long-term, utilisation of the existing renewable energy potential and the huge possibilities for increasing energy efficiency are sufficient to meet future energy demands in the short-term. 


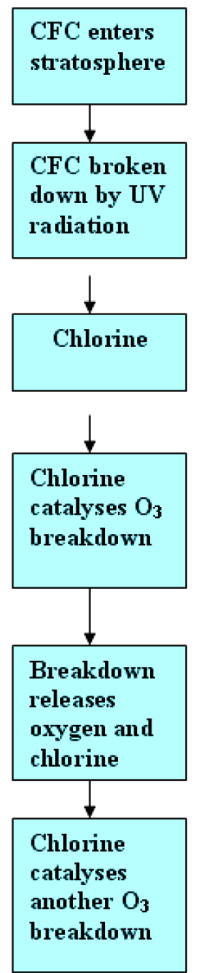

Figure 6. The process of ozone depletion [5].

A total shift towards a sustainable energy system is a complex and long process, but is one that can be achieved within a period of about 20 years. Implementation will require initial investment, long-term national strategies and action plans. However, the changes will have a number of benefits including: a more stable energy supply than at present, and major improvement in the environmental performance of the energy sector, and certain social benefits. A national vision [12] used a methodology and calculations based on computer modelling that utilised:

- Data from existing governmental programmes.

- Potential renewable energy sources and energy efficiency improvements.

- Assumptions for future economy growth.

- Information from studies and surveys on the recent situation in the energy sector.

In addition to realising the economic potential identified by the National Energy Savings Programme, a longterm effort leading to a $3 \%$ reduction in specific electricity demand per year after 2020 is proposed. This will require: further improvements in building codes, and continued information on energy efficiency.

The environmental Non Governmental Organisations (NGOs) are urging the government to adopt sustainable development of the energy sector by:

- Diversifying of primary energy sources to increase the contribution of renewable and local energy resources in the total energy balance.

- Implementing measures for energy efficiency increase at the demand side and in the energy transformation sector.

The price of natural gas is set by a number of market and regulatory factors that include:

Supply and demand balance and market fundamentals, weather, pipeline availability and deliverability, storage inventory, new supply sources, prices of other energy alternatives and regulatory issues and uncertainty.

Classic management approaches to risk are well documented and used in many industries. This includes the following four broad approaches to risk:

- Avoidance includes not performing an activity that could carry risk. Avoidance may seem the answer to all risks, but avoiding risks also means losing out on potential gain.

- Mitigation/reduction involves methods that reduce the severity of potential loss.

- Retention/acceptance involves accepting the loss when it occurs. Risk retention is a viable strategy for small risks. All risks that are not avoided or transferred are retained by default.

- Transfer means causing another party to accept the risk, typically by contract.

Methane is a primary constituent of landfill gas (LFG) and a potent greenhouse gas (GHG) when released into the atmosphere. Globally, landfills are the third largest anthropogenic emission source, accounting for about $13 \%$ of methane emissions or over 818 million tones of carbon dioxide equivalent $\left(\mathrm{MMTCO}_{2} \mathrm{e}\right)$ [13] as shown in Figures 7-9.

\subsection{Geothermal Energy}

Geothermal steam has been used in volcanic regions in many countries to generate electricity. The use of geothermal energy involves the extraction of heat from rocks in the outer part of the earth. It is relatively unusual for the rocks to be sufficiently hot at shallow depth for this to be economically attractive. Virtually all the areas of present geothermal interest are concentrated along the margins of the major tectonic plates, which form the sur-

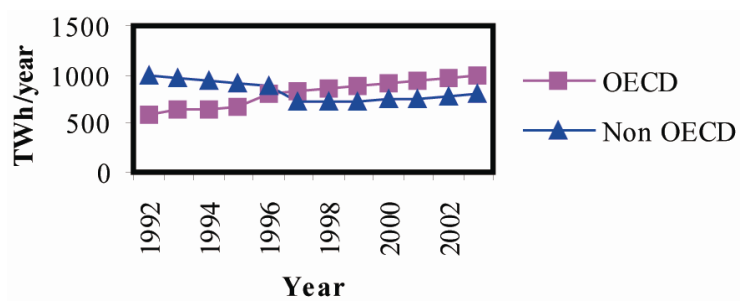

Figure 7. Global CHP trends from 1992-2003 [17]. 


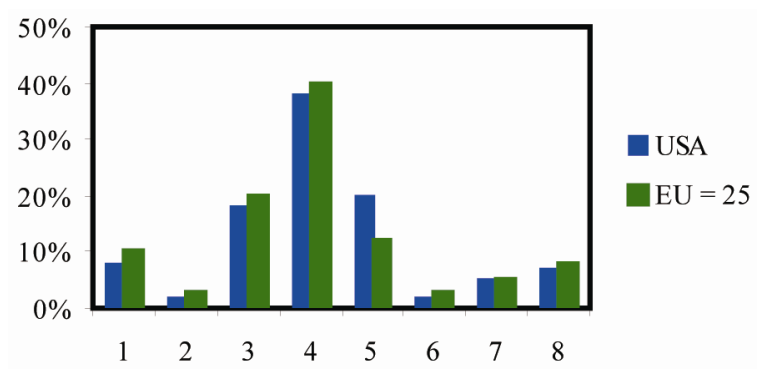

Figure 8. Distribution of industrial CHP capacity in the EU and USA [17]. 1 Food, 2 Textile, 3 Pulp \& paper, 4 Chemicals, 5 Refining, 6 Minerals, 7 Primary metals, and 8 Others.

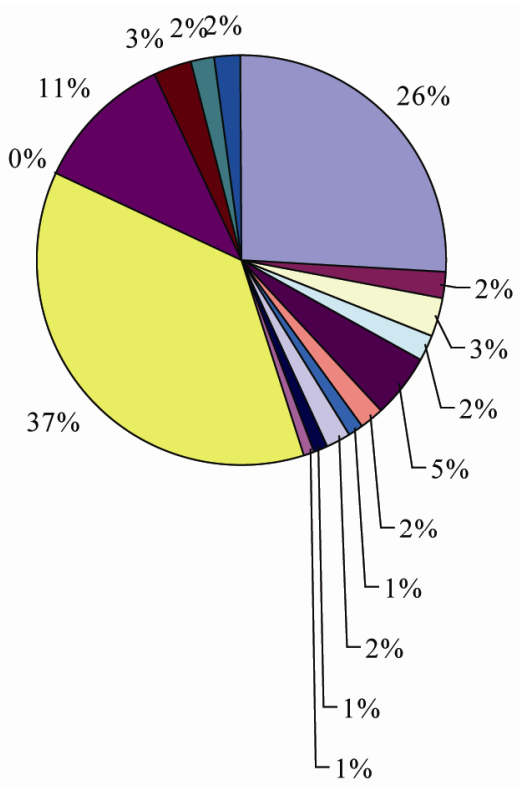

$\begin{array}{llll}\square \text { USA } & \square \text { UK } & \square \text { Ukraine } & \square \text { South Africa } \\ \square \text { Russia } & \square \text { Poland } & \square \text { Nigeria } & \square \text { Mexico } \\ \square \text { Japan } & \square \text { Italy } & \square \text { Others } & \square \text { Colombia } \\ \square \text { China } & \square \text { Canada } & \square \text { Brazil } & \square \text { Australia }\end{array}$

Figure 9. World landfill methane emissions $\left(\mathrm{MMTCO}_{2} \mathrm{e}\right)$ [17].

face of the earth. The forced or natural circulation of water through permeable hot rock conventionally extracts heat.

There are various practical difficulties and disadvantages associated with the use of geothermal power:

Transmission: geothermal power has to be used where it is found. In Iceland it has proved feasible to pipe hot water $20 \mathrm{~km}$ in insulated pipes but much shorter distances are preferred.

Environmental problems: these are somewhat variable and are usually not great. Perhaps the most serious is the disposal of warm high salinity water where it cannot be reinjected or purified. Dry steam plants tend to be very noisy and there are releases of small amounts of methane, hydrogen, nitrogen, amonia and hydrogen sulphide and of these the latter presents the main problem.

The geothermal fluid is often highly chemically corrosive or physically abrassive as the result of the entrained solid matter it carries. This may entail special plant design problems and unusually short operational lives for both the holes and the installations they serve.

Because the useful rate of heat extraction from a geothermal field is in nearly all cases much higher than the rate of conduction into the field from the underlying rocks, the mean temperatures of the field is likely to fall during exploitation. In some low rainfall areas there may also be a problem of fluid depletion. Ideally, as much as possible of the geothermal fluid should be reinjected into the field. However, this may involve the heavy capital costs of large condensation installations. Occasionally, the salinity of the fluid available for reinjection may be so high (as a result of concentration by boiling) that is unsuitable for reinjection into ground. Ocasionally, the impurities can be precipitated and used but this has not generally proved commercially attractive.

World capacity of geothermal energy is growing at a rate of $2.5 \%$ per year from a 2005 level of $28.3 \mathrm{GW}$ [13]. The GSHPs account for approximately $54 \%$ of this capacity almost all of it in the North America and Europe [13]. The involvement of the UK is minimal with less than $0.04 \%$ of world capacity and yet is committed to substantial reduction in carbon emission beyond the $12.5 \%$ Kyoto obligation to be achieved by 2012. The GSHPs offer a significant potential for carbon reduction and it is therefore expected that the market for these systems will rise sharply in the UK in the immediate years ahead given to low capacity base at present.

There are numerous ways of harnessing low-grade heat from the ground for use as a heat pump source or air conditioning sink. For small applications (residences and small commercial buildings) horizontal ground loop heat exchangers buried typically at between $1 \mathrm{~m}$ and $1.8 \mathrm{~m}$ below the surface can be used provided that a significant availability of land surrounding the building can be exploited which tends to limit these applications to rural settings.

Heat generation within the earth is approximately 2700 $\mathrm{GW}$, roughly an order of magnitude greater than the energy associated with the tides but about four orders less than that received by the earth from the sun [7].

Temperature distributions within the earth depend on:

- The abundance and distribution of heat producing elements within the earth.

- The mean surface temperature (which is controlled 
by the ocean/atmosphere system).

- The thermal properties of the earth's interior and their lateral and radial variation.

- Any movements of fluid or solid rock materials occurring at rates of more than a few millimetres per year.

Of these four factors the first two are of less importance from the point of view of geothermal energy. Mean surface temperatures range between $0^{\circ} \mathrm{C}-30^{\circ} \mathrm{C}$ and this variation has a small effect on the useable enthalpy of any flows of hot water. Although radiogenic heat production in rocks may vary by three orders of magnitude, there is much less variation from place to place in the integrated heat production with depth. The latter factors, however, are of great importance and show a wide range of variation. Their importance is clear from the relationship:

where:

$$
\beta=\mathrm{q} / \mathrm{k}
$$

$\beta$ is the thermal gradient for a steady state $\left({ }^{\circ} \mathrm{C} / \mathrm{km}\right), \mathrm{q}$ is the heat flux $\left(10^{-6} \mathrm{cal} \cdot \mathrm{cm}^{-2} \cdot \mathrm{sec}^{-1}\right)$ and $\mathrm{k}$ is the thermal conductivity $\left(\mathrm{cal} \cdot \mathrm{cm}^{-1} \cdot \mathrm{sec}^{-1} \cdot{ }^{\circ} \mathrm{C}^{-1}\right)$.

The first requirement of any potential geothermal source region is that $\beta$ being large, i.e., that high rock temperatures occur at shallow depth. Beta will be large if either $\mathrm{q}$ is large or $\mathrm{k}$ is small or both. By comparison with most everyday materials, rocks are poor conductors of heat and values of conductivity may vary from $2 \times 10^{-3}$ to $10^{-2} \mathrm{cal} \cdot \mathrm{cm}^{-1} \cdot \mathrm{sec}^{-1} \cdot{ }^{\circ} \mathrm{C}^{-1}$. The mean surface heat flux from the earth is about 1.5 heat flow units $\left(1 \mathrm{HFU}=10^{-6}\right.$ $\left.\mathrm{cal} \cdot \mathrm{cm}^{-2} \cdot \mathrm{sec}^{-1}\right)$ [7]. Rocks are also very slow respond to any temperature change to which they are exposed, i.e., they have a low thermal diffusivity:

$$
K=k / \rho \cdot C_{p}
$$

where:

$K$ is thermal diffusivity; $\rho$ and $C_{p}$ are density and specific heat respectively.

These values are simple intended to give a general idea of the normal range of geothermal parameters (Table 6). In volcanic regions, in particular, both $\mathrm{q}$ and $\beta$ can vary considerably and the upper values given are somewhat nominal.

\subsection{Landfill Gap}

Landfill gas (LFG) is currently extracted at over 1200

Table 6. Values of geothermal parameters [16].

\begin{tabular}{cccc}
\hline Parameter & Lower & Average & Upper \\
\hline $\mathrm{q}(\mathrm{HFU})$ & 0.8 & 1.5 & 3.0 (non volcanic) $\approx 100$ \\
$($ volcanic) \\
$\mathrm{k}=\mathrm{cal} \cdot \mathrm{cm}^{-2} \cdot \mathrm{sec}^{-1} \cdot{ }^{\circ} \mathrm{C}^{-1}$ & $2 \times 10^{-3}$ & $6 \times 10^{-3}$ & $12 \times 10^{-3}$ \\
$\beta={ }^{\circ} \mathrm{C} / \mathrm{km}$ & 8 & 20 & 60 (non volcanic) $\approx 300$ \\
& & & (volcanic) \\
\hline
\end{tabular}

landfills worldwide for a variety of energy purposes (Table 7), such as:

- $\quad$ Creating pipeline quality gas or an alternative fuel for vehicles.

- Processing the LFG to make it available as an alternative fuel to local industrial or commercial customers.

- Generation of electricity with engines, turbines, micro-turbines and other emerging technologies.

In terms of solid waste management policy, many NGOs have changed drastically in the past ten years from a mass production and mass consumption society to 'material-cycle society'. In addition to national legislation, municipalities are legally obliged to develop a plan for handling the municipal solid waste (MSW) generated in administrative areas. Such plans contain:

- Estimates of future waste volume.

- Measures to reduce waste.

- Measures to encourage source separation.

- A framework for solid waste disposal and the construction and management of solid waste management facilities.

Landfilling is in the least referred tier of the hierarchy of waste management options: Waste minimisation, reuse and recycling, incineration with energy recovery, and optimised final disposal. The key elements are as follows: construction impacts, atmospheric emissions, noise, water quality, landscape, visual impacts, socio economics, ecological impacts, traffic, solid waste disposal and cultural heritage.

\section{Energy Efficiency}

Energy efficiency is the most cost-effective way of cutting carbon dioxide emissions and improvements to households and businesses. It can also have many other additional social, economic and health benefits, such as warmer and healthier homes, lower fuel bills and company running costs and, indirectly, jobs. Britain wastes 20 per cent of its fossil fuel and electricity use. This im-

Table 7. Types of LFG implemented recently worldwide.

\begin{tabular}{lcc}
\hline Landsill caps & Electricity generation & Fuel production \\
$\square$ Soil caps & $\square$ Reciprocating & $\square$ Medium BTU gas \\
$\square$ Clay caps & $\square$ engines & $\square$ High BTU gas \\
$\square$ Geo-membrane caps & $\square$ Combustion turbines & $\square$ Liquefied methane \\
& $\square$ Micro-turbines & \\
LFG destruction & $\square$ Steam turbines & Thermal generation \\
$\square$ Flares & $\square$ Fuel cells & $\square$ Boilers \\
$\square$ Candlestick & & $\square$ Kilns \\
$\square$ Enclosed & CHP & $\square$ Greenhouse heaters \\
& $\square$ Turbines & $\square$ Leachate evaporators \\
& $\square$ Engines & \\
\hline
\end{tabular}


plies that it would be cost-effective to cut $£ 10$ billion a year off the collective fuel bill and reduce $\mathrm{CO}_{2}$ emissions by some 120 million tones. Yet, due to lack of good information and advice on energy saving, along with the capital to finance energy efficiency improvements, this huge potential for reducing energy demand is not being realised. Traditionally, energy utilities have been essentially fuel providers and the industry has pursued profits from increased volume of sales. Institutional and market arrangements have favoured energy consumption rather than conservation. However, energy is at the centre of the sustainable development paradigm as few activities affect the environment as much as the continually increasing use of energy. Most of the used energy depends on finite resources, such as coal, oil, gas and uranium. In addition, more than three quarters of the world's consumption of these fuels is used, often inefficiently, by only one quarter of the world's population. Without even addressing these inequities or the precious, finite nature of these resources, the scale of environmental damage will force the reduction of the usage of these fuels long before they run out.

Throughout the energy generation process, there are impacts on the environment on local, national and international levels, from opencast mining and oil exploration to emissions of the potent greenhouse gas carbon dioxide in ever increasing concentration. Recently, the world's leading climate scientists reached an agreement that human activities, such as burning fossil fuels for energy and transport, are causing the world's temperature to rise. The Intergovernmental Panel on Climate Change has concluded that "the balance of evidence suggests a discernible human influence on global climate". It predicts a rate of warming greater than any one had seen in the last 10,000 years, in other words, throughout human history. The exact impact of climate change is difficult to predict and will vary regionally. It could, however, include sea level rise, disrupted agriculture and food supplies and the possibility of more freak weather events such as hurricanes and droughts. Indeed, people already are waking up to the financial and social, as well as the environmental, risks of unsustainable energy generation methods that represent the costs of the impacts of climate change, acid rain and oil spills. The insurance industry, for example, concerned about the billion dollar costs of hurricanes and floods, has joined sides with environmentalists to lobby for greenhouse gas emissions reduction. Friends of the earth are campaigning for a more sustainable energy policy, guided by the principal of environmental protection and with the objectives of sound natural resource management and long-term energy security. The key priorities of such an energy policy must be to reduce fossil fuel use, move away from nuclear power, improve the efficiency with which energy is used and increase the amount of energy obtainable from sustainable and renewable energy sources. Efficient energy use has never been more crucial than it is today, particularly with the prospect of the imminent introduction of the climate change levy (CCL). Establishing an energy use action plan is the essential foundation to the elimination of energy waste. A logical starting point is to carry out an energy audit that enables the assessment of the energy use and determine what actions to take. The actions are best categorised by splitting measures into the following three general groups:

\section{1) High Priority/Low Cost}

These are normally measures, which require minimal investment and can be implemented quickly. The followings are some examples of such measures:

- Good housekeeping, monitoring energy use and targeting waste-fuel practices.

- $\quad$ Adjusting controls to match requirements.

- Improved greenhouse space utilisation.

- Small capital item time switches, thermostats, etc.

- Carrying out minor maintenance and repairs.

- Staff education and training.

- Ensuring that energy is being purchased through the most suitable tariff or contract arrangements.

\section{2) Medium Priority/Medium Cost}

Measures, which, although involve little or no design, involve greater expenditure and can take longer to implement. Examples of such measures are listed below:

- New or replacement controls.

- Greenhouse component alteration, e.g., insulation, sealing glass joints, etc.

- $\quad$ Alternative equipment components, e.g., energy efficient lamps in light fittings, etc.

\section{3) Long Term/High Cost}

These measures require detailed study and design. They can be best represented by the followings:

- Replacing or upgrading of plant and equipment.

- Fundamental redesign of systems, e.g., combined heat and power CHP installations.

This process can often be a complex experience and therefore the most cost-effective approach is to employ an energy specialist to help.

\subsection{Policy Recommendations for a Sustainable Energy Future}

Sustainability is regarded as a major consideration for both urban and rural development. People have been exploiting the natural resources with no consideration to the effects, both short-term (environmental) and long-term (resources crunch). It is also felt that knowledge and technology have not been used effectively in utilising energy resources. Energy is the vital input for economic 
and social development of any country. Its sustainability is an important factor to be considered. The urban areas depend, largely, on commercial energy sources. The rural areas use non-commercial sources like firewood and agricultural wastes. With the present day trends for improving the quality of life and sustenance of humankind, environmental issues are considered highly important. In this context, the term energy loss has no significant technical meaning. Instead, the exergy loss has to be considered, as destruction of exergy is possible. Hence, exergy loss minimisation will help in sustainability.

The development of a renewable energy in a country depends on many factors. Those important to success are listed below:

\subsubsection{Motivation of the Population}

The population should be motivated towards awareness of high environmental issues, and rational use of energy in order to reduce cost. Subsidy programme should be implemented as incentives to install biomass energy plants. In addition, image campaigns to raise awareness of renewable technology.

\subsubsection{Technical Product Development}

To achieve technical development of biomass energy technologies the following should be addressed:

- Increasing the longevity and reliability of renewable technology.

- Adapting renewable technology to household technology (hot water supply).

- Integration of renewable technology in heating technology.

- Integration of renewable technology in architecture, e.g., in the roof or façade.

- Development of new applications, e.g., solar cooling.

- Cost reduction.

\subsubsection{Distribution and Sales}

Commercialisation of biomass energy technology requires:

- Inclusion of renewable technology in the product range of heating trades at all levels of the distribution process (wholesale, and retail).

- Building distribution nets for renewable technology.

- Training of personnel in distribution and sales.

- Training of field sales force.

\subsubsection{Consumer Consultation and Installation}

To encourage all sectors of the population to participate in adoption of biomass energy technologies, the following has to be realised:

- Acceptance by craftspeople, and marketing by them.

- Technical training of craftspeople, initial and follow-up training programmes.
- $\quad$ Sales training for craftspeople.

- Information material to be made available to craftspeople for consumer consultation.

\subsubsection{Projecting and Planning}

Successful application of biomass technologies also require:

- Acceptance by decision makers in the building sector (architects, house technology planners, etc.).

- Integration of renewable technology in training.

- Demonstration projects/architecture competitions.

- Biomass energy project developers should prepare to participate in the carbon market by:

1) Ensuring that renewable energy projects comply with Kyoto Protocol requirements.

2) Quantifying the expected avoided emissions.

3) Registering the project with the required offices.

4) Contractually allocating the right to this revenue stream.

- Other ecological measures employed on the development include:

1) Simplified building details.

2) Reduced number of materials.

3) Materials that can be recycled or reused.

4) Materials easily maintained and repaired.

5) Materials that do not have a bad influence on the indoor climate (i.e., non-toxic).

6) Local cleaning of grey water.

7) Collecting and use of rainwater for outdoor purposes and park elements.

8) Building volumes designed to give maximum access to neighbouring park areas.

9) All apartments have visual access to both backyard and park.

\subsubsection{Energy Saving Measures}

The following energy saving measures should also be considered:

- Building integrated solar PV system.

- Day-lighting.

- Ecological insulation materials.

- Natural/hybrid ventilation.

- Passive cooling.

- Passive solar heating.

- Solar heating of domestic hot water.

- Utilisation of rainwater for flushing.

Improving access for rural and urban low-income areas in developing countries must be through energy efficiency and renewable energies. Sustainable energy is a prerequisite for development. Energy-based living standards in developing countries, however, are clearly below standards in developed countries. Low levels of access to affordable and environmentally sound energy in both rural and urban low-income areas are therefore a 
predominant issue in developing countries. In recent years many programmes for development aid or technical assistance have been focusing on improving access to sustainable energy, many of them with impressive results.

Apart from success stories, however, experience also shows that positive appraisals of many projects evaporate after completion and vanishing of the implementation expert team. Altogether, the diffusion of sustainable technologies such as energy efficiency and renewable energies for cooking, heating, lighting, electrical appliances and building insulation in developing countries has been slow.

Energy efficiency and renewable energy programmes could be more sustainable and pilot studies more effective and pulse releasing if the entire policy and implementation process was considered and redesigned from the outset. New financing and implementation processes are needed, which allow reallocating financial resources and thus enabling countries themselves to achieve a sustainable energy infrastructure. The links between the energy policy framework, financing and implementation of renewable energy and energy efficiency projects have to be strengthened and capacity building efforts are required.

\subsection{Environmental Aspects of Energy Conversion and Use}

Environment has no precise limits because it is in fact a part of everything. Indeed, environment is, as anyone probably already knows, not only flowers blossoming or birds singing in the spring, or a lake surrounded by beautiful mountains. It is also human settlements, the places where people live, work, rest, the quality of the food they eat, the noise or silence of the street they live in. Environment is not only the fact that our cars consume a good deal of energy and pollute the air, but also, that we often need them to go to work and for holidays. Obviously man uses energy just as plants, bacteria, mushrooms, bees, fish and rats do. Man largely uses solar energy-food, hydropower, wood- and thus participates harmoniously in the natural flow of energy through the environment. But man also uses oil, gas, coal and nuclear power. By using such sources of energy, man is thus modifying his environment.

The atmospheric emissions of fossil fuelled installations are mosty aldehydes, carbon monoxide, nitrogen oxides, sulpher oxides and particles (i.e., ash) as well as carbon dioxide. Table 8 shows estimates include not only the releases occuring at the power plant itself but also cover fuel extraction and treatment, as well as the storage of wastes and the aea of land required for operations. Table 9 shows energy consumption in diffe-
Table 8. Annual greenhouse emissions from different sources of power plants.

\begin{tabular}{ccccc}
\hline Primary source & \multicolumn{2}{c}{ Emissions } & Waste $\left(\times \mathbf{1 0}^{\mathbf{3}}\right.$ & Area $\left(\mathbf{k m}^{\mathbf{2}}\right)$ \\
\cline { 2 - 3 } of energy & Atmosphere & Water & metric tons) & A \\
\hline Coal & 380 & $7-41$ & $60-3000$ & 120 \\
Oil & $70-160$ & $3-6$ & negligible & $70-84$ \\
Gas & 24 & 1 & - & 84 \\
Nuclear & 6 & 21 & 2600 & 77 \\
\hline
\end{tabular}

rent regions of the world.

\subsection{Greenhouses Environment}

Greenhouse cultivation is one of the most absorbing and rewarding forms of gardening for anyone who enjoys growing plants. The enthusiastic gardener can adapt the greenhouse climate to suit a particular group of plants, or raise flowers, fruit and vegetables out of their natural season. The greenhouse can also be used as an essential garden tool, enabling the keen amateur to expand the scope of plants grown in the garden, as well as save money by raising their own plants and vegetables. There was a decline in large private greenhouses during the two world wars due to a shortage of materials for their construction and fuel to heat them. However, in the 1950s mass-produced, small greenhouses became widely available at affordable prices and were used mainly for raising plants [18]. Also, in recent years, the popularity of conservatories attached to the house has soared. Modern double-glazing panels can provide as much insulation as a brick wall to create a comfortable living space, as well as provide an ideal environment in which to grow and display tender plants.

The comfort in a greenhouse depends on many environmental parameters. These include temperature, relative humidity, air quality and lighting. Although greenhouse and conservatory originally both meant a place to house or conserve greens (variegated hollies, cirrus, myrtles and oleanders), a greenhouse today implies a place in which plants are raised while conservatory usually describes a glazed room where plants may or may not play a significant role. Indeed, a greenhouse can be used for so many different purposes. It is, therefore, difficult to

Table 9. Energy consumption in different continents.

\begin{tabular}{ccc}
\hline Region & Population (millions) & Energy $\left(\mathrm{Watt} / \mathrm{m}^{2}\right)$ \\
\hline Africa & 820 & 0.54 \\
Asia & 3780 & 2.74 \\
Central America & 180 & 1.44 \\
North America & 335 & 0.34 \\
South America & 475 & 0.52 \\
Western Europe & 445 & 2.24 \\
Eastern Europe & 130 & 2.57 \\
Oceania & 35 & 0.08 \\
Russia & 330 & 0.29 \\
\hline
\end{tabular}


decide how to group the information about the plants that can be grown inside it.

Throughout the world, urban areas have increased in size during recent decades. About $50 \%$ of the world's population and approximately $76 \%$ in the more developed countries are urban dwellers [18]. Even though there is an evidence to suggest that in many 'advanced' industrialised countries there has been a reversal in the rural-to-urban shift of populations, virtually all population growth expected between 2000 and 2030 will be concentrated in urban areas of the world. With an expected annual growth of $1.8 \%$, the world's urban population will double in 38 years [18]. This represents a serious contributing to the potential problem of maintaining the required food supply. Inappropriate land use and management, often driven by intensification resulting from high population pressure and market forces, is also a threat to food availability for domestic, livestock and wildlife use. Conversion to cropland and urban-industrial establishments is threatening their integrity. Improved productivity of peri-urban agriculture can, therefore, make a very large contribution to meeting food security needs of cities as well as providing income to the periurban farmers. Hence, greenhouses agriculture can become an engine of pro-poor 'trickle-up' growth because of the synergistic effects of agricultural growth such as [18]:

- Increased productivity increases wealth.

- Intensification by small farmers raises the demand for wage labour more than by larger farmers.

- Intensification drives rural non-farm enterprise and employment.

- Alleviation of rural and peri-urban poverty is likely to have a knock-on decrease of urban poverty.

Despite arguments for continued large-scale collective schemes, there is now an increasingly compelling argument in favour of individual technologies for the development of controlled greenhouses. The main points constituting this argument are summarised by [18] as follows:

- Individual technologies enable the poorest of the poor to engage in intensified agricultural production and to reduce their vulnerability.

- Development is encouraged where it is needed most and reaches many more poor households more quickly and at a lower cost.

- Farmer-controlled greenhouses enable farmers to avoid the difficulties of joint management.

Such development brings the following challenges [19]:

- The need to provide farmers with ready access to these individual technologies, repair services and technical assistance.
- Access to markets with worthwhile commodity prices, so that sufficient profitability is realised.

- This type of technology could be a solution to food security problems. For example, in greenhouses, advances in biotechnology like the genetic engineering, tissue culture and market-aided selection have the potential to be applied for raising yields, reducing pesticide excesses and increasing the nutrient value of basic foods.

However, the overall goal is to improve the cities in accordance with the Brundtland Report [19] and the investigation into how urban green could be protected. Indeed, greenhouses can improve the urban environment in multitude of ways. They shape the character of the town and its neighbourhoods, provide places for outdoor recreation, and have important environmental functions such as mitigating the heat island effect, reduce surface water runoff, and creating habitats for wildlife. Following analysis of social, cultural and ecological values of urban green, six criteria in order to evaluate the role of green urban in towns and cities were prescribed [19]. These are as follows:

- Recreation, everyday life and public health.

- Maintenance of biodiversity - preserving diversity within species, between species, ecosystems, and of landscape types in the surrounding countryside.

- City structure - as an important element of urban structure and urban life.

- Cultural identity - enhancing awareness of the history of the city and its cultural traditions.

- Environmental quality of the urban sites-improvement of the local climate, air quality and noise reduction.

- Biological solutions to technical problems in urban areas - establishing close links between technical infrastructure and green-spaces of a city.

The main reasons why it is vital for greenhouses planners and designers to develop a better understanding of greenhouses in high-density housing can be summarised as follows [20]:

- Pressures to return to a higher density form of housing.

- The requirement to provide more sustainable food.

- The urgent need to regenerate the existing, and often decaying, houses built in the higher density, high-rise form, much of which is now suffering from technical problems.

The connection between technical change, economic policies and the environment is of primary importance as observed by most governments in developing countries, whose attempts to attain food self-sufficiency have led them to take the measures that provide incentives for adoption of the Green Revolution Technology [20]. 
Since, the Green Revolution Technologies were introduced in many countries actively supported by irrigation development, subsidised credit, and fertiliser programmes, self-sufficiency was found to be not economically efficient and often adopted for political reasons creating excessive damage to natural resources. Also, many developing countries governments provided direct assistance to farmers to adopt soil conservation measures. They found that high costs of establishment and maintenance and the loss of land to hedgerows are the major constraints to adoption [20]. The soil erosion problem in developing countries reveals that a dynamic view of the problem is necessary to ensure that the important elements of the problem are understood for any remedial measures to be undertaken. The policy environment has, in the past, encouraged unsustainable use of land [20]. In many regions, government policies such as provision of credit facilities, subsidies, price support for certain crops, subsidies for erosion control and tariff protection, have exacerbated the erosion problem. This is because technological approaches to control soil erosion have often been promoted to the exclusion of other effective approaches. However, adoption of conservation measures and the return to conservation depend on the specific agroecological conditions, the technologies used and the prices of inputs and outputs of production.

\subsubsection{Types of Greenhouses}

Choosing a greenhouse and setting it up are important, and often expensive, steps to take. Greenhouses are either freestanding or lean-to, that is, built against an existing wall. A freestanding greenhouse can be placed in the open, and, hence, take advantage of receiving the full sun throughout the day. It is, therefore, suitable for a wide range of plants. However, its main disadvantage when compared to a lean-to type is that more heat is lost through its larger surface area. This is mainly why leanto greenhouses have long been used in the walled gardens of large country houses to grow Lapageria rosea and other plants requiring cool, constant temperature, such as half-hardly ferns. However, generally, good ventilation and shading in the spring and summer to prevent overheating are essential for any greenhouse. The high daytime temperatures will warm the back wall, which acts as a heat battery, releasing its accumulated heat at night. Therefore, plants in a greenhouse with this orientation will need the most attention, as they will dry out rapidly.

Also, greenhouses vary considerably in their shapes and internal dimensions. Traditional greenhouses have straight sides, which allow the maximum use of internal space, and are ideal for climbers [21]. On the other hand, greenhouses with sloping sides have the advantage of allowing the greatest penetration of sunlight, even during winter [21]. The low winter sun striking the glass at $90^{\circ} \mathrm{C}$ lets in the maximum amount of light. Where the sun strikes the glass at a greater or lesser angle, a proportion of the light is reflected away from greenhouse. Sloping sides, also, offer less wind resistance than straight sides and therefore, less likely to be damaged during windy weather. This type of greenhouse is most suitable for short winter crops, such as early spring lettuce, and flowering annuals from seed, which do not require much headroom.

A typical greenhouse is shown schematically in Figure 10. However, there are several designs of greenhouses, based on dimensions, orientation and function. The following three options are the most widely used:

- A ready-made design.

- A designed, which is constructed from a number of prefabricated modules.

- A bespoke design.

Of these, the prefabricated ready-made design, which is utilised to fit the site, is the cheapest greenhouses and gives flexibility. It is, also, the most popular option [22].

Specific examples of commercially available designs are numerous. Dutch light greenhouses, for example, have large panes of glass, which cast little shade on the plants inside. They are simple to erect, consisting of frames bolted together, which are supported on a steel framework for all but the smallest models. They are easy to move and extra sections can be added on to them, a useful attraction [22]. Curvilinear greenhouses, on the other hand, are designed primarily to let in the maximum amount of light throughout the year by presenting at least one side perpendicular to the sun. This attractive style of greenhouse tends to be expensive because of the number of different angles, which require more engineering [22]. Likewise, the uneven span greenhouses are designed for maximum light transmission on one side. These are generally taller than traditional greenhouses, making them suitable for tall, early season crops, such as cucumbers

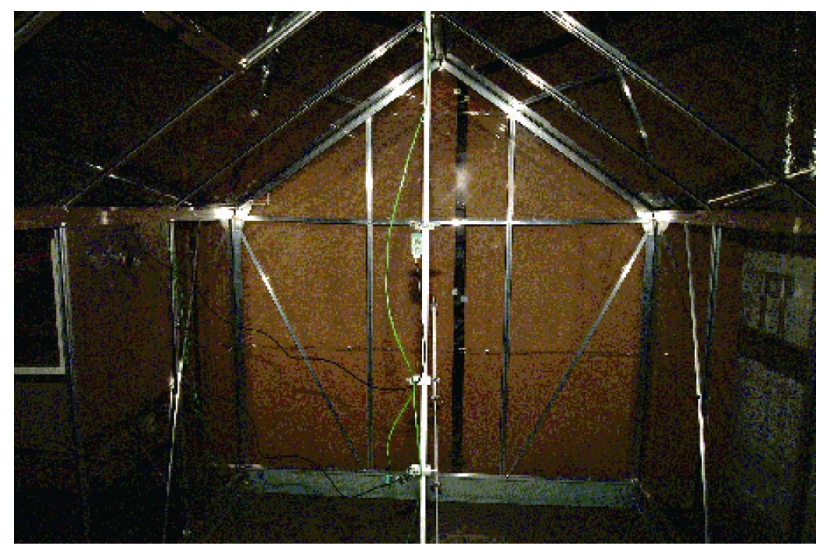

Figure 10. Greenhouse and base with horticultural glass. 
[21]. In addition, the polygonal greenhouses are designed more as garden features than as practical growing houses, and consequently, are expensive. Their internal space is somewhat limited and on smaller models over-heading can be a problem because of their small roof ventilations. They are suitable for growing smaller pot plants, such as pelargoniums and cacti [23]. Another example is the solar greenhouses. These are designed primarily for areas with very cold winters and poor winter light. They take the form of lean-to structures facing the sun, are well insulated to conserve heat and are sometimes partially sunk into the ground. They are suitable for winter vegetable crops and early-sown bedding plants, such as begonias and pelargoniums [23]. Mini lean-to greenhouses are suitable for small gardens where space is limited. They can, also, be used to create a separate environment within larger greenhouses. The space inside is large enough to grow two tomato or melon plants in growing bags, or can install shelves to provide a multi-layered growing environment, ideal for many small potted plants and raising summer bedding plants [23].

\subsubsection{Construction Materials}

Different materials are used for the different parts. However, wood and aluminium are the two most popular materials used for small greenhouses. Steel is used for larger structures and rigid polyvinyl chloride, UPVC for conservatories, which is used mainly in conservatory building, does not decay or rust and is, therefore, maintenance-free [24]. However, after a period of time it can become abraded by dirt in the atmosphere and lose its smart finish. Greenhouses clothed in plastic or glass. Plastic offers the cheapest form of protection, while glass is the most aesthetically pleasing of the two materials.

\subsubsection{Ground Radiation}

Reflection of sunrays is mostly used for concentrating them onto reactors of solar power plants. Enhancing the insolation for other purposes has, so far, scarcely been used. Several years ago, application of this principle for increasing the ground irradiance in greenhouses, glass covered extensions in buildings, and for illuminating northward facing walls of buildings was proposed [25]. Application of reflection of sun's rays was motivated by the fact that ground illuminance/irradiance from direct sunlight is of very low intensity in winter months, even when skies are clear, due to the low incident angle of incoming radiation during most of the day. This is even more pronounced at greater latitudes. As can be seen in Figure 11, which depicts a sunbeam split into its vertical and horizontal components, nearly all of the radiation passes through a greenhouse during most of the day.

The primary objective of greenhouses is to produce agricultural products outside the cultivation season. They

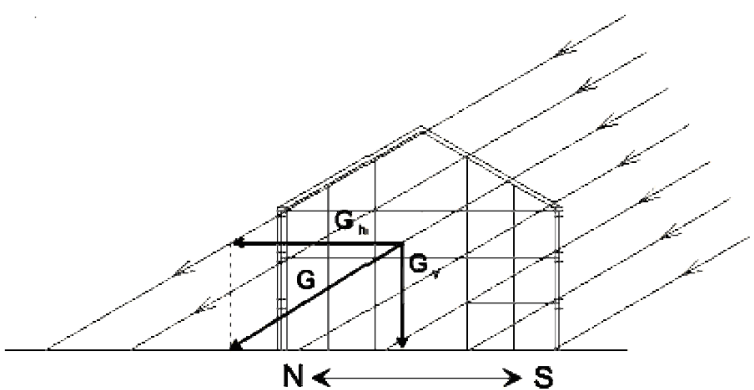

Figure 11. Relative horizontal and vertical components of solar radiation.

offer a suitable microclimate for plants and make possible growth and fruiting, where it is not possible in open fields. This is why a greenhouse is also known as a "controlled environment greenhouse". Through a controlled environment, greenhouse production is advanced and can be continued for longer duration, and finally, production is increased [26]. The off-season production of flowers and vegetables is the unique feature of the controlled environment greenhouse. Hence, greenhouse technology has evolved to create the favourable environment, or maintaining the climate, in order to cultivate the desirable crop the year round. The use of "maintaining the climate" concept may be extended for crop drying, distillation, biogas plant heating and space conditioning.

\section{Conclusions}

Two of the most essential natural resources for all life on the earth and for man's survival are sunlight and water. Sunlight is the driving force behind many of the renewable energy technologies. The worldwide potential for utilising this resource, both directly by means of the solar technologies and indirectly by means of biofuels, wind and hydro technologies is vast. During the last decade, interest has been refocused on renewable energy sources due to the increasing prices and fore-seeable exhaustion of presently used commercial energy sources. Thermal comfort is an important aspect of human life. Buildings where people work require more light than buildings where people live. In buildings where people live the energy is used for maintaining both the temperature and lighting. Hence, natural ventilation is rapidly becoming a significant part in the design strategy for non-domestic buildings because of its potential to reduce the environmental impact of building operation, due to lower energy demand for cooling. A traditional, naturally ventilated building can readily provide a high ventilation rate. On the other hand, the mechanical ventilation systems are very expensive. However, a comprehensive ecological concept can be developed to achieve a reduction of electrical and heating energy consumption, optimise natural air condi- 
tion and ventilation, improve the use of daylight and choose environmentally adequate building materials. Plants, like human beings, need tender loving care in the form of optimum settings of light, sunshine, nourishment, and water. Hence, the control of sunlight, air humidity and temperatures in greenhouses are the key to successful greenhouse gardening. The mop fan is a simple and novel air humidifier; which is capable of removing particulate and gaseous pollutants while providing ventilation. It is a device ideally suited to greenhouse applications, which require robustness, low cost, minimum maintenance and high efficiency. A device meeting these requirements is not yet available to the farming community. Hence, implementing mop fans aides sustainable development through using a clean, environmentally friendly device that decreases load in the greenhouse and reduces energy consumption.

\section{REFERENCES}

[1] G. Robinson, "Changes in Construction Waste Management," Waste Management World, May-June 2007, pp. 43-49.

[2] A. M. Omer and D. Yemen, "Biogas an Appropriate Technology," Proceedings of the 7th Arab International Solar Energy Conference, Sharjah, 19-22 February 2001, p. 417.

[3] D. T. Swift-Hook, et al., "Characteristics of a Rocking Wave Power Devices,” Nature, Vol. 254, 1975, pp. 504-506.

[4] R. H. Sims, "Not Too Late: IPCC Identifies Renewable Energy as a Key Measure to Limit Climate Change," Renewable Energy World, Vol. 10, No. 4, 2007, pp. 31-39.

[5] T. Trevor, "Fridge Recycling: Bringing Agents in from the Cold," Waste Management World, Vol. 5, 2007, pp. 43-47.

[6] International Energy Agency (IEA), "Indicators for Industrial Energy Efficiency and $\mathrm{CO}_{2}$ Emissions: A Technology Perspective," International Energy Agency, Paris, 2007.

[7] G. Brain and S. Mark, "Garbage in, Energy out: Landfill Gas Opportunities for CHP Projects," Cogeneration and On-Site Power, Vol. 8, No. 5, 2007, pp. 37-45.

[8] R. H. D. Rawlings, “Technical Note TN 18/99—Ground Source Heat Pumps: A Technology Review," The Building Services Research and Information Association, Bracknell, 1999.

[9] E. R. Oxburgh, "Geothermal Energy," Aspects of Energy Conversion, 1975, pp. 385-403.

[10] W. John, "The Glasshouse Garden (The Royal Horticultural Society Collection)," Conran Octopus Ltd, UK, 1993.

[11] United Nations, "World Urbanisation Prospect: The 1999 Revision," The United Nations Population Division, New
York, 2001.

[12] World Commission on Environment and Development (WCED), "Our Common Future," Oxford University Press, New York, 1987.

[13] G. Herath, "The Green Revolution in Asia: Productivity, Employment and the Role of Policies," Oxford Agrarian Studies, Vol. 14, 1985, pp. 52-71.

[14] E. Jonathon, "Greenhouse Gardening," The Crowood Press Ltd, UK, 1991.

[15] P. Achard and R. Gicqquel, "European Passive Solar Handbook," Commission of the European Communities, Brussels, 1986.

[16] M. O. Abdeen, "Energy in Europe: Economics, Policy and Strategy-IB," NOVA Science Publishers, Inc., New York, 2008, pp. 341-373.

[17] A. M. Omer, "Environmental and Socio-Economic Aspect of Possible Development in Renewable Energy Use," Proceedings of the 4th International Symposium on Environment, Athens, 21-24 May 2009.

[18] A. M. Omer, "Energy Consumption, Environment and Sustainable Development," Proceedings of the 3rd International Conference on Sustainable Energy and Environmental Protection (SEEP 2009), Dublin, 12-15 August 2009, p. 1011.

[19] A. M. Omer, "Energy Use and Environmental: Impacts: A General Review," Journal of Renewable and Sustainable Energy, Vol. 1, No. 5, 2009, pp. 1-29. doi:10.1063/1.3220701

[20] A. M. Omer, "Environmental Cost Management," NOVA Science Publishers, Inc., New York, 2009, pp. 129-166.

[21] United Nations Environment Programme (UNEP), "Handbook for the International Treaties for the Protection of the Ozone Layer," United Nations Environment Programme, Nairobi, 2003.

[22] World Bank, "World Development Report 2004: Making Services Work for Poor People," World Bank, Washington, D.C., 2004.

[23] A. M. Omer, "Biomass Energy Potential and Future Prospect in Sudan," Renewable \& Sustainable Energy Review, Vol. 9, No. 1. 2005, pp. 1-27. doi:10.1016/j.rser.2003.12.011

[24] J. Singh, et al., "Biomass Conversion to Energy in India: A Critique," Renewable and Sustainable Energy Review, Vol. 14, No. 5, 2008, pp. 1367-1378. doi:10.1016/j.rser.2010.01.013

[25] M. H. Duku, et al., "Comprehensive Review of Biomass Resources and Biofuels Potential in Ghana," Renewable and Sustainable Energy Review, Vol. 15, No. 1, 2009, pp. 404-415. doi:10.1016/j.rser.2010.09.033

[26] Cheng, et al., "Advanced Biofuel Technologies: Status and Barriers," World Bank Report, WPS5411, 2010. 
Nomenclature

a: annum

ha: hectares
HFU: heat flow unit

1: litre

MSW: municipal sewage waste 